\title{
Characteristics of Tigris River Bed at Mosul City, Iraq*
}

\author{
Khalil I. Othman, Wang Deguan \\ (College of Environmental Science and Engineering, Hohai University, Nanjing, 210098, P.R.China)
}

\begin{abstract}
Evaluation study of natural characteristics of $55 \mathrm{~km}$ reach of Tigris riverbed material located at the Mosul city area was conducted. The main objective of the study is to analyze the surface and subsurface bed material at the located reach, and to explain the armoring condition in Tigris riverbed. From the result analysis of the field and laboratory work of the collected samples from the surface and subsurface layers of the riverbed material, it was concluded that Tigris riverbed had been reached previously the armoring condition. In general the grain size distribution of the surface layer decreased with distance along the study reach of the river. The riverbed material was approaching the homogeneous condition Finally the surface bed material particles have mainly the disc spherical, cylindrical and blade shape by a percentage of $48.34 \%, 25.2 \%, 15.34 \%$ and $11.08 \%$ respectively. While the dominant size in the surface and subsurface layer was very coarse gravel by percentage of $74 \%$ and $36 \%$ respectively.
\end{abstract}

Keywords: Armoring; Tigris River; surface and subsurface bed material

Generally river running through deep layers of alluvial sediments or sand will change its flow and sediment regime after closure of dam constructed across this river. The clear water released by the dam due to the sediment deposition processes occurred upstream of the dam will erode the downstream channel causing rapid degradation immediately below the dam. The sediment removed from the bed by the clear water consists to a large extent of fine particles causing the bed material to become coarser and coarser while the sediment rate decreased with time and the bed roughness will increases. Thus decreasing flow velocity until stable bed is attained in equilibrium condition. This condition of the bed surface coarsening is called the phenomenon of armoring ${ }^{[1]}$.Studying the characteristics of the river bed material specially after constructing a big hydraulic structures across this river (Like a dam) is an important subject due the significant changes occur in the size distribution of the bed along the rive, the shape of the bed material, quantity of sediment transport and the resistance to flow.

Tigris river passes through deep alluvial layers in the north region of Iraq, which recently change its flow and sediment regime specially after constructing Saddam dam in 1985. For example the average monthly amount of suspended sediment concentration of Tigris river at

* Correspondence author. E-mail: Khalil_othman@ @otmail.com 
Mosul city have been estimated to be $1100 \mathrm{~g} / 10^{6} \mathrm{~g}$ before Saddam dam construction ${ }^{[2]}$. While it decreased recently after Saddam dam construction to become $59 \mathrm{~g} / 10^{6} \mathrm{~g}^{[3]}$. Limited number of studies were conducted on Tigris river before Saddam dam closure by researchers concerning bed material analysis specially on its north part near Mosul city such as Nedico ${ }^{[4,5]}$, $\mathrm{Najib}^{[6]}$ and Khaleel ${ }^{[7]}$. Therefore it is necessary to conduct another new and supplementary studies on Tigris River after Saddam dam construction.

The aim of the present research was focused on the evaluation of the natural characteristic of Tigris riverbed material and directed toward the phenomenon of riverbed armoring after Saddam dam closure.

\section{Study Reach}

Six locations along a reach of $55 \mathrm{~km}$ long from Tigris River extend between Saddam Regulating dam and Mosul city were selected to collect the samples of surface and subsurface bed material to conduct this study. The first site is located 200 meters downstream Saddam Regulating dam, the second at Wana village, the third near Badoosh dam, the fourth is Rashidia village, While the fifth and sixth are near Al-Shohadaa and Saddam Mosul bridges respectively (Fig.1). Many factors were taken into consideration in the selection of these sites for bed material sampling to assure a morphological simulated condition between these sites.

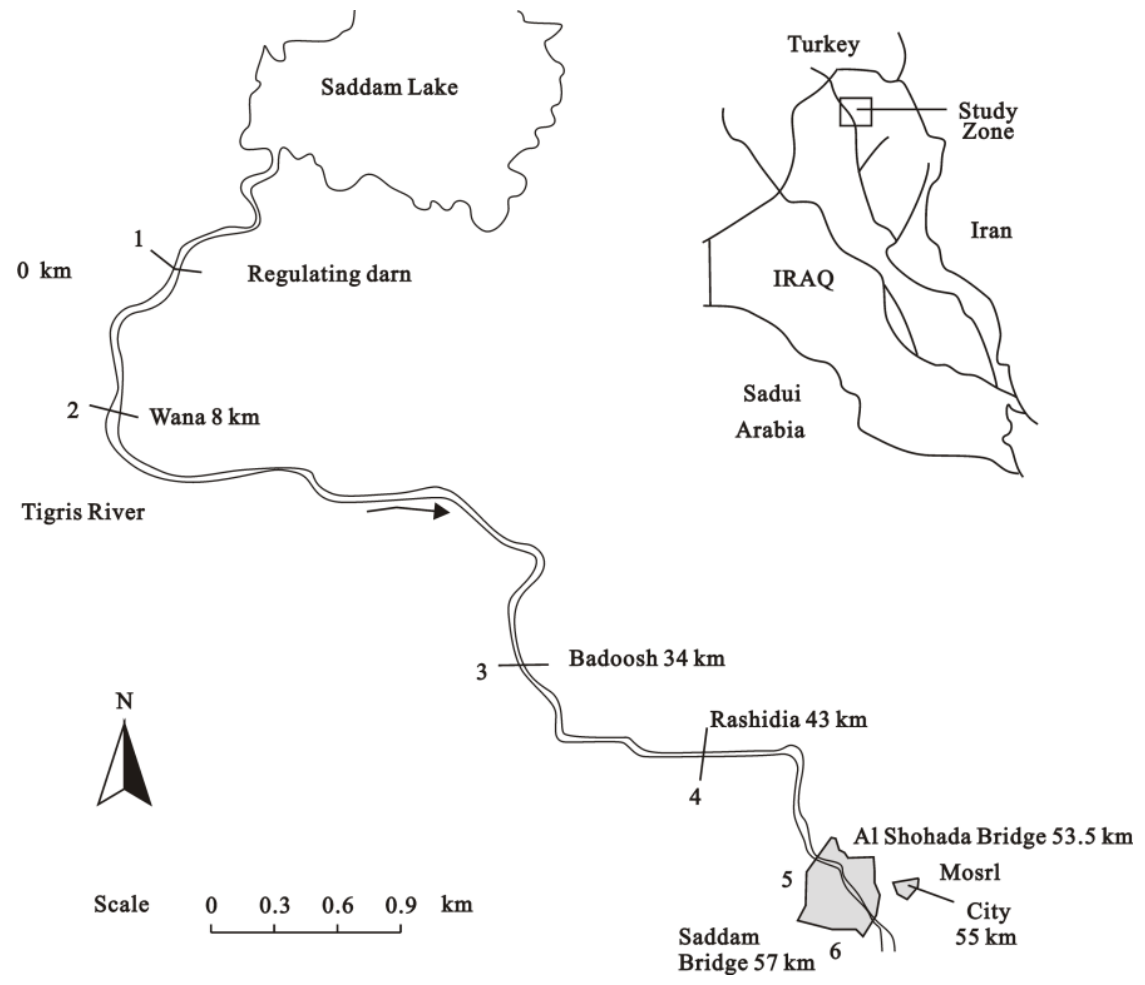

Fig. 1 Location map of the study area 


\subsection{Sampling of Bed Material}

In general bed material of Tigris River in studied reach is gravel ${ }^{[4]}$, therefore two distinct layers surface and subsurface are recognized. The surface layer is often called the paved or armored layer. According to Adms ${ }^{[8]}$, rivers are considered paved if their surface and subsurface layers are composed of particles that are similar in their size but lack sand and fine gravel in the surface layer and armored if the particles of the surface layer are much coarser than the subsurface layer. Consequently different sampling methods should be followed to determine the characteristics of these layers. Transect method was used for the sampling of surface layer. A measuring tape was extended on the surface of the gravel bed shore perpendicular to the direction of flow and at least 100 particles were collected at regular intervals of $0.3 \mathrm{~m}$ along the extend tape. A hand tool excavator was used to remove the surface layer, and then subsurface sample was taken. The representative sample size is determined according to Barry ${ }^{[9]}$ method. This procedure was used to collect the samples at the selected six locations along the study reach as shown in Fig.1. Three samples were collected for surface bed and 5 samples for subsurface bed material at each location. The samples of each location are mixed to get one sample for surface bed material and one sample for subsurface bed material to care out the required analysis.

Three mutually perpendicular axes of the surface layer particles, the longest (a-axis), the intermediate (b-axis), the shortest (c-axis) were measured. The size distribution analysis of surface layer was found numerically according to the b-axis length, which is proportional to the sieve diameter. While the size distribution of the subsurface layer was found using set of sieves.

\section{Results and discussion}

\subsection{Surface Layer Analysis}

The grain size distribution of the present tested bed material samples for the study reach of Tigris River was shown in Fig.2. The median diameter $\left(D_{50}\right)$ of these curves varied between $72 \mathrm{~mm}$ at the Regulating Saddam and 34mm at Saddam Mosul Bridge. This indicates that the bed material near the dam was coarser than bed material size at Wana and decreasing downstream toward Mosul city see Fig.3. This figure describe decreasing relation of the $\mathrm{D}_{90}, \mathrm{D}_{84}, \mathrm{D}_{65}, \mathrm{D}_{50}$ and $\mathrm{D}_{16}$ of the surface layer with distance along the study reach, where $\mathrm{D}_{90} \mathrm{D}_{84}, \mathrm{D}_{65}, \mathrm{D}_{50}$ and $\mathrm{D}_{16}$ are the sieve diameter in which $90 \% 84 \% 65 \% 50 \% 16 \%$ of the material are finer respectively. This also give an indication that due to the released clear water discharge from Saddam dam, the fine bed material have washed and transported downstream leaving the large sizes of bed material. The percent of washed fine particles near the Regulating dam is larger than the other site downstream due to the large water power existed in the released clear water discharge from the Regulating Saddam dam. Comparison of the present bed material gradation analysis curves at Mosul site with different authors was shown in Fig.4. From this comparison, it was found that the value of the median diameter of the present analysis has an agreement with Nedico ${ }^{[5]}$ and khaleel ${ }^{[7]}$ but more than found by $\mathrm{Najib}^{[6]}$. In addition it was observed that the value of $\mathrm{D}_{16}$ is 
more than that found by Khaleel ${ }^{[7]}$. This may be attributed to the washing and transportation processes occur in the fine material only as a result of the effect of released water discharge from the dam.

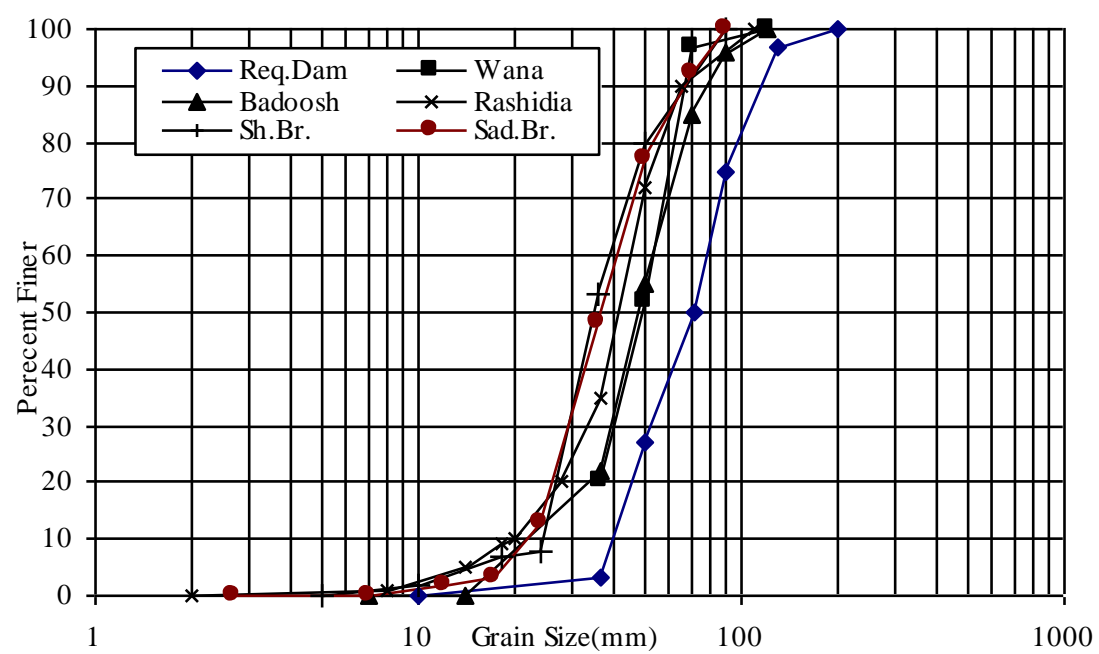

Fig. 2 Grain size distribution of surface layer bed material of Tigris river for the study reach

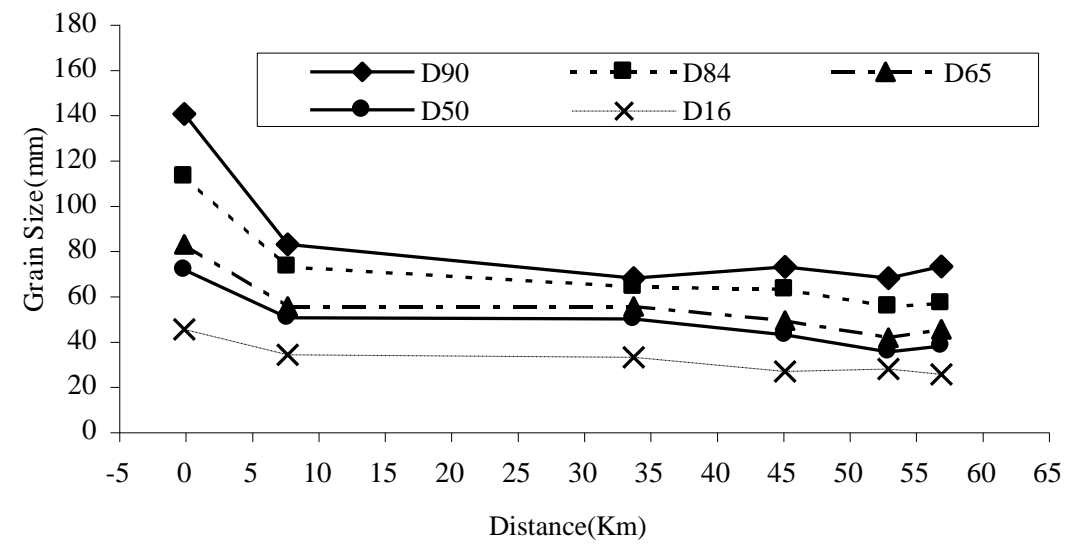

Fig. 3 Variation of grain size distribution of surface layerbed material for the study reach.

The median particle size $\left(D_{50}\right)$ is commonly used by researchers as an indicator of streambed material characteristics, therefore an attempt was made to correlate a relation in the changes in the median size of the surface layer with distance downstream for the studied reach (Fig.5), which can be represented by the following equation with correlation coefficients 0.95 .

$$
D_{50}(\text { at any } \mathrm{X})=D_{50}(\text { at } X=0)-0.465 X
$$

Where $X$ is the distance along the study reach in kilometers

The homogeneity of the bed material can be evaluated by the geometric standard deviation $\sigma$ 
$=\left(D_{84} / D_{16}\right)$. The above characteristic of the surface bed material was calculated for all the study sites as shown in Tab.1. While Tab.2 introduces this ratio at Mosul site for different authors.

Tab. 1 Geometric standard deviation of the bed material of Tigris river

\begin{tabular}{cccccc}
\hline $\begin{array}{c}\text { Regulating } \\
\text { Dam }\end{array}$ & Wana & $\begin{array}{c}\text { Badoosh } \\
\text { Dam }\end{array}$ & Rashidia & $\begin{array}{c}\text { Al-Shohada } \\
\text { Bridge }\end{array}$ & $\begin{array}{c}\text { Saddam } \\
\text { Bridge }\end{array}$ \\
\hline 1.57 & 1.44 & 1.37 & 1.53 & 1.4 & 1.48 \\
\hline
\end{tabular}

Tab. 2 Geometric standard deviation of the bed material of Tigris river at Mosul site for different authors.

\begin{tabular}{cccc}
\hline Nedico $^{[5]}$ & Najib $^{[6]}$ & Khaleel $^{[7]}$ & Present Work \\
\hline 1.61 & 2.19 & 1.73 & 1.55 \\
\hline
\end{tabular}

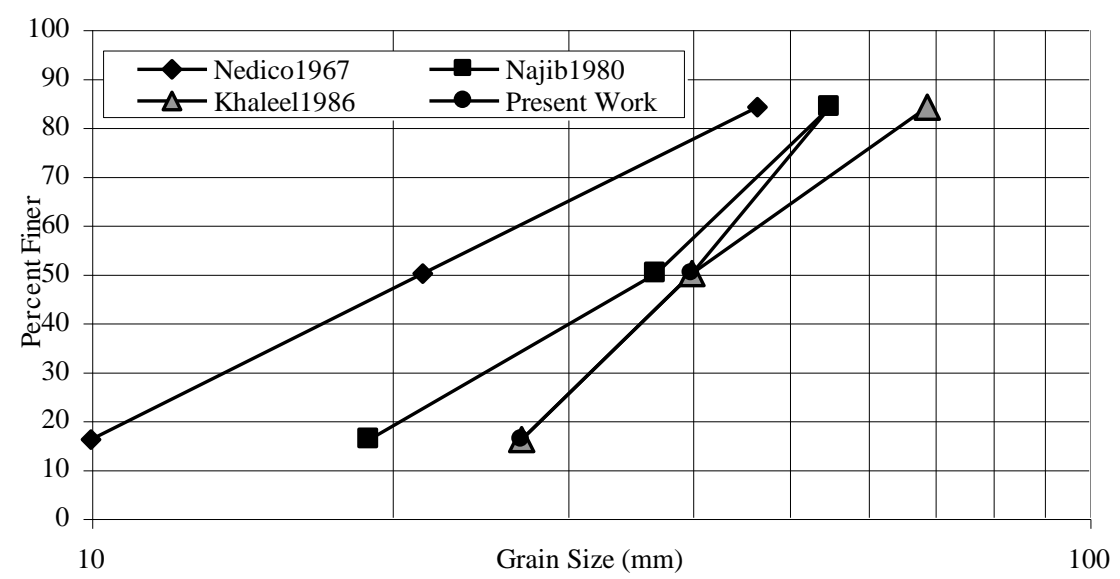

Fig. 4 Comparison of grain size distribution of surface layer of Tigris river bed at Mosul for different authors

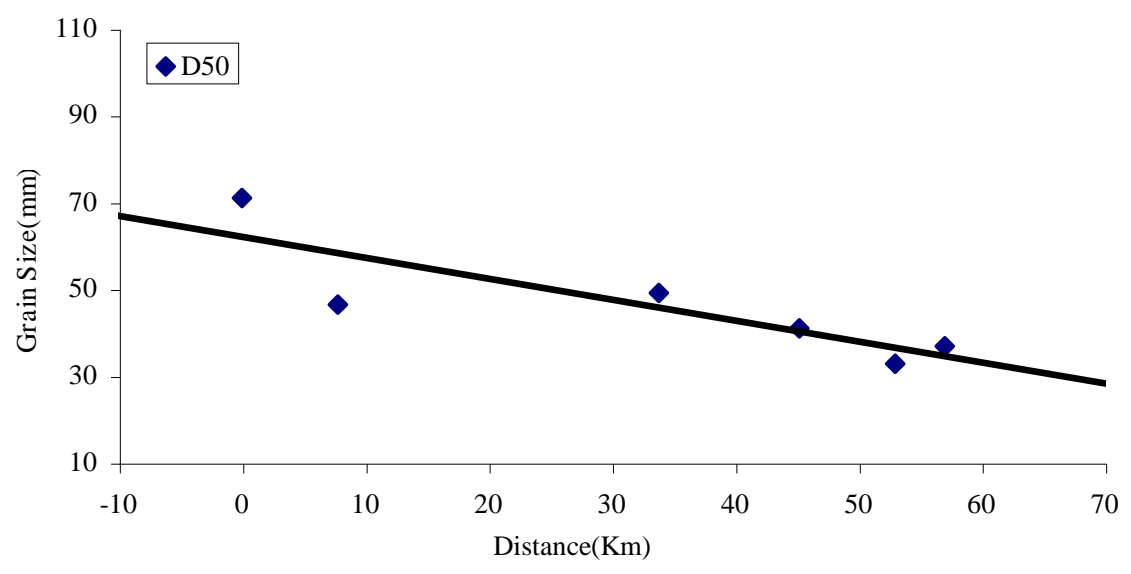

Fig.5 Variation of median diameter of surface layer bed material with distance along study reach 
It was clear from these tables that the geometric standard deviation decreased with time and distance which gave indicate that Tigris river began to approach the homogeneous condition specially after Saddam dam closure.

\subsection{Subsurface Layer Analysis}

The grain size distribution analysis of the present subsurface material of Tigris river at the study sites was presented in Tab. 3. This table shows that the values of $\mathrm{D}_{50}$ of subsurface layer at the study river reach ranges between $12 . \mathrm{mm}$ and $22 . \mathrm{mm}$ table 4 . introduces a comparison between the above subsurface bed material analysis at Mosul site with different authors. From Tab. 3 and 4 it was observed that there is no any indication about that systematic changes occur in the subsurface layer with time and distance. This may be due to existed natural protection by coarse surface layer material.

Tab. 3 Grain size distribution analysis of subsurface of Tigris river bed material

\begin{tabular}{lccccccc}
\hline Site & $D 10(\mathrm{~mm})$ & $D 16(\mathrm{~mm})$ & $D 30(\mathrm{~mm})$ & $D 50(\mathrm{~mm})$ & $D 65(\mathrm{~mm})$ & $D 84(\mathrm{~mm})$ & D90(mm) \\
\hline Reg.Dam & 0.4 & 0.42 & 2.5 & 12.0 & 27.6 & 51.6 & 58.6 \\
Wana & 0.2 & 0.45 & 12.2 & 19.0 & 23.8 & 32.0 & 35.7 \\
Badoosh & 0.2 & 0.3 & 7.0 & 22.4 & 29.7 & 45.0 & 56.5 \\
Rashidia & 0.4 & 0.54 & 5.0 & 14.1 & 22.2 & 36.0 & 49.8 \\
Sh. Br. & 0.4 & 0.54 & 4.0 & 12.2 & 20.5 & 35.2 & 49.8 \\
Sadd. Br. & 0.5 & 0.61 & 3.1 & 13.1 & 21.4 & 36.3 & 48.9 \\
\hline
\end{tabular}

Tab. 4 Grain size distribution analysis of the subsurface bed material

of Tigris river at the Mosul for different authors

\begin{tabular}{ccccccccc}
\hline \multirow{2}{*}{ Author } & \multicolumn{7}{c}{ Grain Size (mm) } \\
\cline { 2 - 8 } & $D 10$ & $D 16$ & $D 30$ & $D 50$ & $D 65$ & $D 70$ & $D 84$ & $D 90$ \\
\hline Nedico $^{[4]}$ & & 4.8 & & 16 & & & 54 & \\
Nedico $^{[5]}$ & & 0.5 & 1.7 & 8 & 12 & 13 & 18 & 25 \\
Al.Shaikh $^{[10]}$ & & 2.9 & & 18 & & & 46 & \\
Najib $^{[6]}$ & & 0.8 & 2.7 & 14 & 19 & 20 & 34 & 40 \\
Kirikche $^{[2]}$ & 0.14 & 0.56 & 4.3 & 15 & 23 & 28 & 40 & 47 \\
Gannia $^{[11]}$ & 0.28 & 1.1 & 5.6 & 17 & 25 & 30 & 50 & 65 \\
Present work & 0.45 & 0.58 & 3.56 & 12.7 & 20 & 23 & 35.8 & 48.9 \\
\hline
\end{tabular}

Generally it is difficult and tedious job to find the real characteristics of surface layer of the riverbed material. However the characteristics of the subsurface layer can be found easier. Therefore a statistical relationship between the median diameter of the surface and subsurface layer was conducted along the study reach to predict the properties of the surface layer from the analysis of subsurface layer. This relationship was represented by the following equation with correlation coefficient 0.98 .

$$
D_{50 \text { surface }}=4.022 \times\left(D_{50 \text { subsurface }}\right)^{0.09} \times \sigma_{(\text {subsurface })}
$$


By this equation, it able to predict the median size of surface bed material along the study area after knowing the $D_{50}$ and geometric standard deviation of subsurface bed material, which can be found in easy way by using sieve analysis technique.

\subsection{River Bed Armoring}

Different essential criteria presented by many authors were dependent in the present work to check and describe the armoring condition in this reach of Tigris River as listed in table 5. Lapshenkove ${ }^{[12]}$ stated that the necessary condition for bed armoring can given when the ratio of $D_{90}$ of the surface layer to the $D_{50}$ is larger than 5 . While Gessler ${ }^{[13]}$ considered the bed to be armored when the ratio $D_{84} / D_{50}$ more than 2, finally Komura and Simons ${ }^{[14]}$ and Suryanarayana and Shen ${ }^{[15]}$ introduce the armoring condition when the value of the $D_{50}$ of the surface layer is more than or equal to the $D_{84}$ of the subsurface layer.

Tab. 5 Application of different standard criteria for surface bed material to be armored.

\begin{tabular}{|c|c|c|c|c|c|c|c|}
\hline \multirow[t]{2}{*}{ Author } & \multirow[t]{2}{*}{ Criteria } & \multicolumn{6}{|c|}{ Site } \\
\hline & & Reg.Dam & Wana & Badoosh & Rashidia & Al Sho.Br & Sadd. Bri. \\
\hline Lapshenkov $^{[12]}$ & $D_{90} / D_{50}>5$ & 1.93 & 1.61 & 1.29 & 1.63 & 1.86 & 1.82 \\
\hline Gessler ${ }^{[13]}$ & $D_{84} / D_{16}>2$ & 1.54 & 1.49 & 1.25 & 1.43 & 1.52 & 1.46 \\
\hline Komua\&Simons $^{[14]}$ & $D_{50}$ sur $/ D_{84} \mathrm{sub}>1$ & 1.39 & 1.53 & 1.13 & 1.19 & 1.03 & 1.12 \\
\hline
\end{tabular}

From the Tab. 5 it was observed that method used by Lapshenkov ${ }^{[12]}$ and Gessler ${ }^{[13]}$ did not gave indication that Tigris rive at the study site had reached the armoring condition, while method use by Komura and Simons ${ }^{[14]}$ gave this indication. This may be due to the different riverbed formation components and conditions dependent by Lapshenkov ${ }^{[12]}$ and Gessler ${ }^{[13]}$ than Tigris river bed. From the presents results and previous works it may conclude that Tigris bed had been reached previously the armoring condition before Saddam dam constriction and large percentage of fine gravel bed material had been washed and transported. In the same time Saddam dam construction add another energy by the releases clear water to wash and carry the remained fine materials existed in the surface layer. This may reflect on scouring and degradation processes occur in Tigris riverbed downstream the Regulating dam site.

\subsection{Classification of the bed material}

From the length measurements of the particle axes of the surface layer and using Zing diagram, it appears that the percentage of the particles have blade shape in all the tested sites i. e (Regulating dam, Wana, Badoosh, Rashidia, Al-Shohada Bridge and Saddam Bridge in Mosul city are14.2,6.98, 14.71, 13.2512 .35 and 4.92 respectively, The percentages of particle having disc shape for the same sites are $52.43,58.14,58.82,44.4$ and 27.87 respectively while the percentage of spherical particles are 20,19.77, 14.71, 20.48, 37.04 and 39.34. Finally the percentage of the 
cylindrical particles are 14.29,15.12, 11.76,16.87,16.17, and 27.87. The above shape classification was shown in Fig. 6 which in general gave an indication that the surface layer of

Tigris river bed consist mainly from the disc particles by an average value of $48.35 \%$ then spherical of $25.22 \%$, cylindrical of $15.34 \%$ and blade particles of $11.08 \%$. To evaluate another

characteristics of the surface particle, the shape factor of the bed material particles was calculated for the study sites according to Schulz,et.al ${ }^{[16]}$ as listed in Tab. 6 which was estimated

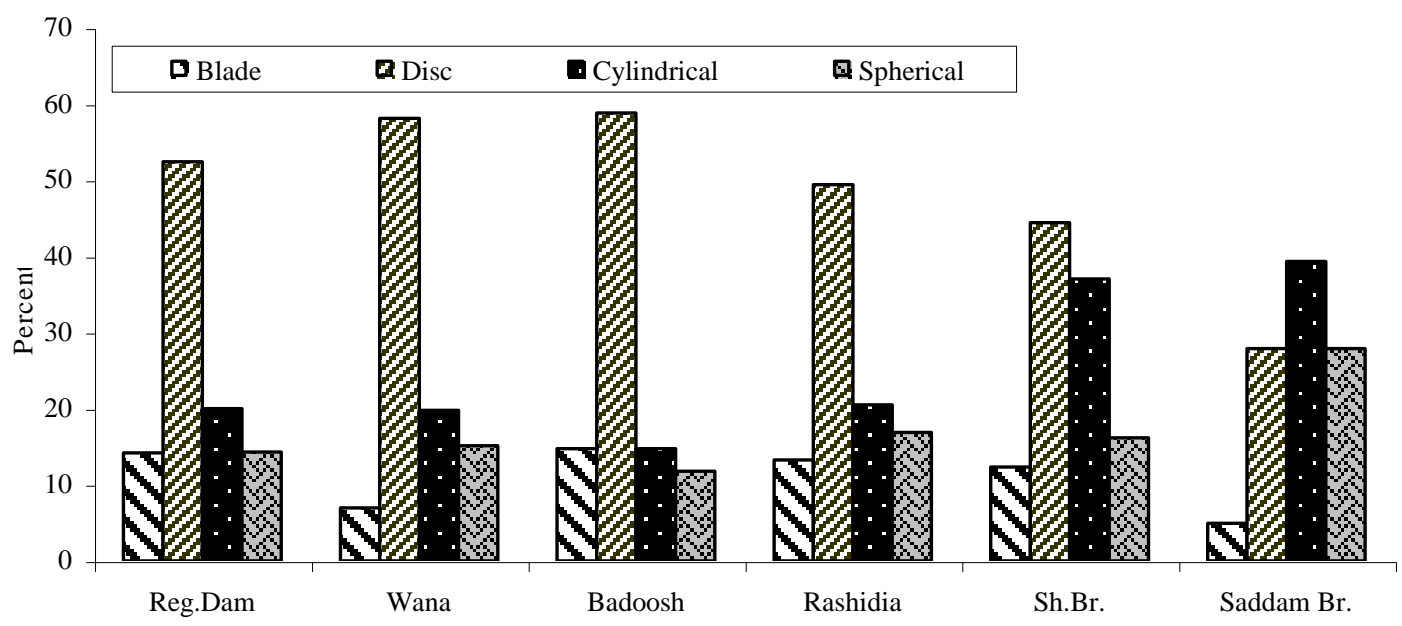

Fig. 6 Shape classification of the surface bed material of Tigris river

Tab. 6 Average value of sphericity and shape factor of the surface bed material particles

\begin{tabular}{ccccccc}
\hline Site & Reg. Dam & Wana & Badoosh & Rashidia & Al-sho.Br & Sadd. Br. \\
\hline Sphericity & 0.67 & 0.69 & 0.69 & 0.69 & 0.69 & 0.71 \\
Shape Factor & 0.51 & 0.51 & 0.51 & 0.54 & 0.53 & 0.59 \\
\hline
\end{tabular}

by an average value of 0.53 . Sphericity of the particles that defined as the ratio of surface area of the sphere of the same volume as the particle to the actual surface area of the particle was calculated to using Krumbein ${ }^{[17]}$ method. It is clear from the table that the average value of the sphericity of the Tigris river bed particle in the study sites was 0.68 and this characteristic increased with the distance along the study reach of river due to the erosion processes occur in particle edges during its transportation with flowing discharges. The size classification of the bed material (surface and subsurface of Tigris river was conducted according to Rouse ${ }^{[18]}$ as shown in Tab. 7. From the table it was found that the dominant size represents the surface and subsurface layer bed material was very coarse gravel by percentages of $74 \%$ and $36 \%$ respectively. 
Tab. 7 Type classification of the bed material of Tigris river according to Rouse ${ }^{[18]}$ method

\begin{tabular}{cccc}
\hline Size $(\mathrm{mm})$ & Surface layer(\%) & Subsurface layer $(\%)$ & Classes \\
\hline $250-130$ & 2 & - & Large Cobble \\
$130-64$ & 20.5 & 5 & Small Cobble \\
$64-32$ & 74 & 37 & Very Coarse Gravel \\
$32-16$ & 1.5 & 10 & Coarse Gravel \\
$16-8$ & 2 & 14 & Medium Gravel \\
$8-4$ & - & 8 & Fine Gravel \\
$4-2$ & - & 2 & Very Fine Gravel \\
$2-1$ & - & 3 & Very Coarse Sand \\
$1-0.5$ & - & 3 & Coarse Sand \\
$<0.5$ & - & 18 & Fine sand (silt \&clay) \\
\hline
\end{tabular}

\section{Conclusion}

Tigris riverbed under the study area may have reached the armoring condition before the Saddam dam closure. The presence of the dam increased the armoring capability of the riverbed by washing the remaining fine bed materials. It found that the geometric standard deviation of the surface layer particles decreased with time and distance along the river, which give an indication that the riverbed material was approached to the homogeneous condition. The shape of the surface layer particles was mainly disc $(48.35 \%)$, then spherical $(25.22 \%)$, cylindrical $(15.34 \%)$ and blade (11.08\%). While the shape factor and sphericity of surface bed materials was 0.53 and 0.68 respectively. The dominant size in the surface and subsurface layer was very coarse gravel by a percentage of $74 \%$ and $36 \%$ respectively. From the analysis of this study it can conclude that operation of Saddam dam under normal operation condition will never cerate any noticeable changes in the characteristics of Tigris river bed in the future, this mean that the river under the study site are almost at the stable condition.

\section{References}

1 Little W C, Mayer P G. Stability of River Channel Bed by Armoring. Journal of Hydraulic Division, ASCE, 1976, 102(Hy11)

2 Kirikche E M. Sediment Characteristics of Tigris River Between Zakho and Fatha, M. Sc Thesis. Irrigation Department, College of Engineering, Mosul Univ., Iraq, 1985

3 Al-Taiee T M. The Influence of Dam on the Degradation of Downstream River Bed, Proceeding of the International Conference on the Hydrology in Mountainous Region, Switzerland, 1990

4 Nedico. Study of the Navigation in Tigris River Between Baghdad and Mosul, Republic of raq, Ministry of Development, 1958

5 Nedico. Navigation Study Tigris River, Mosul-Baghdad Reach, Republic of Iraq, Planning Report, 1976

6 Najib Y E. Characteristics of Tigris River at Mosul, M.Sc. Thesis Presented to the University of Mosul, College of Engineering, Iraq, 1980

7 Khaleel M S. Analysis of Surface Layer Material of Tigris river at Mosul city, Report, College of Engineering, Irrigation and 
Drainage Department, University of Mosul, Iraq, 1986

8 Adams J.Gravel Size Analysis From Photography. Proc Amer Soc Civ Eng, 1979, 105 (Hy10):1247-1256

9 Bary D I. Regime Relation For Alberta Gravel Bed Rivers. Proc. of Hydrology Symposium of Fluvial Processes and Sedimentation, University of Alberta, Edmonton, Alberta, 1972. 440-453

10 Al-Shaikh Ali K, Mohmood T. A. Source Dangers on Al-Hurriah Bridge in Mosul. Al-Rafidain Eng. Journal, University of Mosul, Mosul, Iraq, 1976,2(1)

11 Gannia A. A hydraulic Model to study and Train Tigris River Between Ninavah Bridge and Al-Hurriya Bridge at Mosul City. M. Sc Thesis Presented to the University of Mosul, College of Engineering, Iraq,1987

12 Lapshenkove V S.Prediction of River Channel Deformation Up and Downstream From Dams, Gidrometeomizdat, Leningrad, 1979

13 Gessler J. Self Stabilizing Tendencies of Alluvial Channels, Am. Soci. Of Civil Eng. Journal of Waterways and Harbors Div, 1970.96(ww2):235-249

14 Komura S, Simons D B. River Bed Degradation Below Dams, Journal of the Hydraulic Division, ASCE, 1967,93(Hy4):1-14

15 Suryanarayana B, Shen H W. Laboratory Study of Degradation and Aggregation, Journal Of Waterways, Harbors and Coastal Eng. Div. ASCE, 1970,93(ww4):615-631

16 Schulz E F, Wild R H, Albertson M L. Influence of shape on the Fall Velocity of Sedimentary Particles. New York: ,Jone Wiley, 1950:776

17 Krumbien W C. Measurement and Geologic Significance of Shape and Roughness of Sedimentary Particles, Journal of Sediment Petroleum, 1941,11:64-72

18 Rouse H. Engineering Hydraulics, Proceedings of the 4 th hydraulics conference, Iowa Institute of hydraulic research. New York: Jone Wiley, 1950:776

\section{伊拉克底格里斯河摩苏尔河段特性分析}

Khalil I. Othman 汪德爟

( 河海大学环境科学与工程学院, 南京 210098 )

\section{提 要}

采用天然河道实测资料分析和实验室试验分析方法，对伊拉克底格里斯河摩苏尔 $55 \mathrm{~km}$ 河段的河道床 沙组成进行研究, 目的是分析河床表层及底层泥沙组成, 以及该河段的床沙粗化条件. 通过收集天然河道 的床沙资料，对沙样进行实验室分析，结果表明：底格里斯河摩苏尔河段床沙已形成粗化：一般河床表 层泥沙颗粒大小分布随着河段距离的增加而减小，床沙接近于均匀分布，表层床沙沙样颗粒中圆盘形、 球形、柱形和片状分别为 $48.34 \% 、 25.2 \% 、 15.34 \%$ 和 $11.08 \%$. 在床沙的表层和底层泥沙以粗沙砾石为 主, 分别为 $74 \%$ 和 $36 \%$.

\section{关键词 粗化 底格里斯河 床沙表层和底层}

分类号 